\title{
CUSTOMER PERCEPTION OF BANDUNG CITY SOCIETYON E-MONEY USAGE FOR THE HIGHWAY SERVICE PAYMENT
}

\author{
Michael Tanu', Rita Komaladewi', \& Heni Iswati2
}

IUniversitas Padjajaran, Bandung, Indonesia

2Universitas Budi Luhur, Jakarta, Indonesia

E-mail: michael.tanu08@gmail.com, rita.komaladewi@unpad.ac.id \& heni.iswati@gmail.com

\begin{abstract}
E-commerce has been used in many business transactions because of its practicality and easiness for the users. In addition, it also provides easiness in control. The use of electronic money (e-money) as a non-cash payment alternative has a huge potential in decreasing the use of cash money. E-money provides faster and more comfortable transactions compared to the cash money, especially for the small-amount transactions. With e-money, every transaction is simpler, cheaper, and easier both for the buyers and sellers. One of the government interventions has recently been that every highway transaction can only be paid using e-money. This policy has resulted in a various response from the consumers or society at large. This research is aimed at exploring the perception of the consumers or society in Bandung on e-money policy for highway service payment. The method used in this research is a descriptive method. The data collection techniques used are literature study and questionnaire distributed to 100 respondents who ever used e-money in their transaction. The results of this research showed that the implementation of e-money is already good. But, there are some constraints in the aspect of service and technology. Those things are based on the measurement using the basic model of Technology Acceptance Model (TAM).
\end{abstract}

Keywords: E-money, Technology Acceptance Model, Customer's Perception JEL Classification: M39

\begin{abstract}
ABSTRAK
E-commerce telah digunakan dalam banyak transaksi bisnis karena praktis dan mudah bagi pengguna. Selain itu, juga memberikan kemudahan dalam kontrol. Penggunaan uang elektronik (e-money) sebagai alternatif pembayaran non tunai memiliki potensi besar dalam mengurangi penggunaan uang tunai. E-money menyediakan transaksi yang lebih cepat dan lebih nyaman dibandingkan dengan uang tunai, terutama untuk transaksi dalam jumlah kecil. Dengan e-money, setiap transaksi lebih sederhana, lebih murah, dan lebih mudah bagi pembeli dan penjual. Salah satu intervensi pemerintah baru-baru ini adalah bahwa setiap transaksi jalan raya hanya dapat dibayar menggunakan uang elektronik. Kebijakan ini telah menghasilkan berbagai tanggapan dari konsumen atau masyarakat luas. Penelitian ini bertujuan untuk mengeksplorasi persepsi konsumen atau masyarakat di Bandung tentang kebijakan e-money untuk pembayaran layanan jalan raya. Metode yang digunakan dalam penelitian ini adalah metode deskriptif. Teknik pengumpulan data yang digunakan adalah studi literatur dan kuesioner yang dibagikan kepada 100 responden yang pernah menggunakan vang elektronik dalam transaksi mereka. Hasil penelitian ini menunjukkan bahwa implementasi e-money sudah baik. Namun, ada beberapa kendala dalam aspek layanan dan teknologi. Hal-hal tersebut didasarkan pada pengukuran menggunakan model dasar Technology Acceptance Model (TAM).
\end{abstract}

Kata kunci: E-money, Model Penerimaan Teknologi, Persepsi Pelanggan

Klasifikasi JEL: M39 


\section{Michael Tanu \\ Rita Komaladewi \\ Heni Iswati}

\section{INTRODUCTION}

Globalization is an inevitable phenomenon and this is something that is happening. In addition to its economic benefit, it also brings implication to many aspects of human lives. For example, the development in international trades makes it possible for the products manufactured by people in another part of the world to be consumed by Indonesian society, even by those in the village areas. Besides, the development of information and technology enables any international news to be known by society anywhere in the world. If we implement those two fields, the technology utilization in business is so common, such as in the implementation of the internet or World Wide Web (www). A large number of internet users implies that they are the large potential market for an e-commerce transaction. According to Yang, Wang and Chen (2017), E-commerce provides various goods and services such as electronic gadgets, books, and fashion products. In an e-commerce website, the user or consumer can purchase a product online, wherever and whenever. This provides easiness to any consumer as he or she does not need to go outside the house and stand in line.

The technological development brings changes in society in terms of modern trade and payment instrument providing speed, accuracy, and safety in each transaction. The history has proven that the development of payment instrument kept changing started from metal, conventional paper and the modern money as today. The modern money has evolved by the use of electronic data storage.

The use of electronic money as an alternative of the non-cash instrument has reduced the dependency on the cash money. Electronic money provides a faster and more comfortable transaction compared to the cash money, especially for the small-amount transactions. This is possible because electronic money can be used easier, cheaper and securer both for the buyers and the sellers. Nonetheless, there are some constraints or issues with e-money. The first constraint is the difficulty in checking the balance of the e-money when performing the transaction. So, the consumers often do not know their balance (Wulandari, 2016). The second constraint is that only a few merchants accepting e-money in Indonesia. Another problem with e-money is that it does not use a pin or password, so if we lost it, it can be misused by other people with ease. One of the high-value transactions is the payment of highway. According to the government policy, payments for highway service can only be made using e-money. This policy was issued by the Ministry of Public Works and Housing and Central Bank of Indonesia. This policy aims to make transactions faster and easier. The people of Bandung had various responses to the e-money. Thus, it is interesting to conduct 
research related to the perception of the society from various layers on the use of e-money for microtransactions. It is because there is a possibility in the future that all microtransactions in Indonesia should use e-money, depending on the readiness of the society. Regarding this phenomenon, the Technology Acceptance Model (TAM) can be used as a model to assess and determine the level of public acceptance of the enactment of e-money. This study aims to: 1) know the consumers perception of e-money in Bandung city, and 2) know to what extent the people of Bandung city accept e-money.

\section{LITERATURE REVIEW}

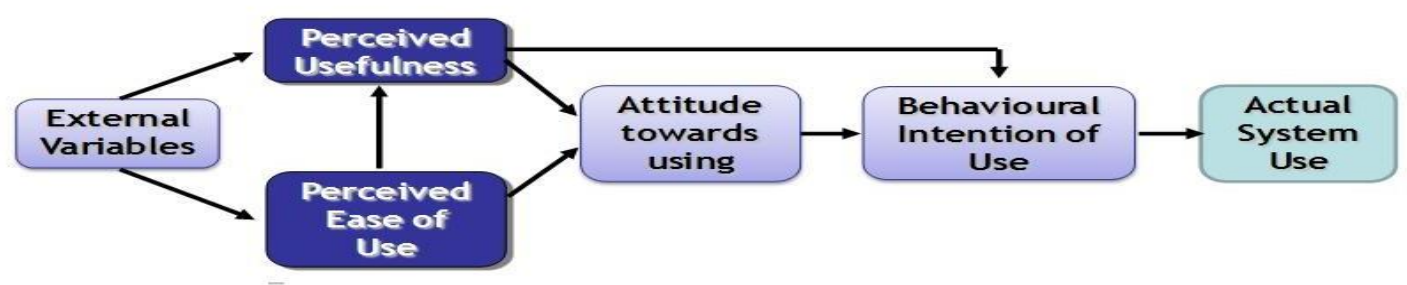

Figure 1. Model Basic Technology Acceptance Model (Davis, 1989).

Davis (1989), Purwianti and Tio (2017), and Fatmawati (2015) stated that the external variable includes self-efficacy which is a personal or individual belief in his or her ability to perform en expected effective task. Some indicators of perception of information system easiness cover a) easiness to be studied, b) easiness to be operated, and c) clear and understandable display. There are some indicators of perceived usefullness, namely, increasing productivity, making work more effective, and increasing the speed of work. Behavioral intention of use is a behavior of a consumer who wants to use a service continuously (loyal). Attitude Towards Using is a behavior of a user on the use of library information system in the form of acceptance or rejection. So, in this behavioral context, the user shall show his behavior, whether he accepts or rejects the information system. Actual Usage is the performance of someone of a certain behavior which can be known clearly from the usage of the information system, namely, the intensity in information system usage, the frequency of using the information system, and the continuous usage of the information system.

Gapar and Akmar (2011) indicated that Technology Acceptance Model has been proven to be a useful theoretical model in helping us to understand and explain the usage of ecommerce because this model offers the useful constructs (usage, easiness, and pleasure). Usman (2017) pointed out that e-money is a prepaid product where some money is stored in an electronic media card owned by the consumers. That "electronic" value is purchased by the consumer and then stored in an electronic medium. The value is deducted whenever 


\section{Michael Tanu \\ Rita Komaladewi \\ Heni Iswati}

the consumer makes the payment for any purchase he made. Waspada (2012) in this research stated that the adoption for e-money is influenced by the benefit perception, transaction easiness, availability of sufficient information, the security level, privacy, and joyfulness in every transaction process. The adoption for e-money in the business world is relatively low and the number of merchants accepting e-money is still small, this is because they prefer the cash transaction.

According to Kotler, Amstrong, Brown and Adam(1998) Consumer perception is described as acting and reacting on what one sees. Lekhanya and Dlamini (2016) proved that perception is defined as a broad imagination that people create in their mind and interpret that imagination as a bigger meaningful picture.

Liligeto, Singh and Naz (2014) argued based on their researchthere are varying factors which impact consumer perception and reaction such as consumers' varied personalities, the surrounding environment, unforeseen circumstances, and the culture.Based on that background, therefore we propose :

\section{H1: The society well accepts e-money as the payment instrument of the highway service}

\section{METHODS}

The method used in this research is descriptive research, namely the research describing the perception of Bandung city society on the usage of e-money. The descriptive research portrays the object, a series of the condition, the system of thought, past event and current event. The sampling technique in this research is purposive sampling, which is sampling which has the criteria of having e-money and using it for more than 6 month. the source of the questionnaire is from final project report (Tanu, 2017) The sample of this research is 100 Bandungs residents interviewed using the questionnaire instrument. The secondary data related to the issue in this study were also collected.

\section{RESULTS}

Table 1. shown that the positive and negative weights of the respondent response are 1300 and 100, respectively. The followings are the percentages of the response on e-money usage for the payment of highway service:

The agreeing respondents $:(1300 / 1400) \times 100 \%=92,8 \%$

The disagreeing respondents $:(100 / 1400) \times 100 \%=7.14 \%$

So, the total weight of those who have accepted e-money as the payment instrument is around $92.8 \%$, meanwhile the weight of those who have not accepted the e-money is 
around $7,14 \%$. The analysis was carried out using values or indicators from the Technology Acceptance Model. What is the customer's perception of the use of e-money related to the ease of use of e-money until the duration or frequency of time. Customer able to operate emoney according to procedures because its is easy use and simple and does not require much effort to operate e-money. Alsohave felt the payment process is faster when using emoney because people do not need to accept change money and do not need to give coins to the cashier, of course accuracy of the payment process when using e-money.

Table 1. Recapitulation of the questionnaire

\begin{tabular}{clccccc}
\hline \multirow{2}{*}{ No } & \multicolumn{1}{c}{ Indicator } & \multicolumn{5}{c}{ Frequency(\%) } \\
\cline { 3 - 6 } & & $\mathbf{1}$ & $\mathbf{2}$ & $\mathbf{3}$ & $\mathbf{4}$ & $\mathbf{5}$ \\
\hline $\mathbf{1}$ & Self Efficacy & 1 & & 15 & 53 & 31 \\
$\mathbf{2}$ & Payment process faster & & 2 & 14 & 58 & 26 \\
$\mathbf{3}$ & Accuracy of the payment process & & 2 & 24 & 59 & 16 \\
$\mathbf{4}$ & Provide a sense of security in transactions & & 5 & 28 & 48 & 19 \\
$\mathbf{5}$ & More efficient than cash & 1 & 7 & 14 & 48 & 30 \\
$\mathbf{6}$ & Easy to use & 2 & 3 & 17 & 40 & 38 \\
$\mathbf{7}$ & Easy to understand & 1 & & 29 & 32 & 38 \\
$\mathbf{8}$ & Practical & 3 & & 16 & 37 & 44 \\
$\mathbf{9}$ & Flexible & & 6 & 21 & 42 & 31 \\
$\mathbf{1 0}$ & Desired as a payment instrument & & 13 & 35 & 43 & 9 \\
$\mathbf{1 1}$ & Useful as a payment instrument & 3 & 8 & 13 & 44 & 32 \\
$\mathbf{1 2}$ & Plan for using e-money in each transaction & 2 & 12 & 42 & 12 & 32 \\
$\mathbf{1 3}$ & The e-money performance is satisfying & 6 & 12 & 15 & 23 & 44 \\
$\mathbf{1 4}$ & Transaction settlement is less than 3 minutes & 2 & 10 & 15 & 51 & 22 \\
\hline & TOtal & $\mathbf{2 0}$ & $\mathbf{8 0}$ & $\mathbf{2 9 8}$ & $\mathbf{5 9 0}$ & $\mathbf{4 1 2}$ \\
\hline
\end{tabular}

E-money transaction are automaticaly connected with the database which make security is assured. The payment process is more efficient by using e-money than cash, people do not need to carry too much cash so that cash is not scattered everywhere. Using e-money is very flexible, it can be use anywhere and anytime when there is a special e-money transaction machine. The desire or interest of the people to use e-money is still low as It does not be provide the machine related to e-money. There is no much businesses in Bandung provide payment facilities using e-money such as retail shops (for example: stalls), street vendors, pulse workers, photocopier of e-money performance has been satisfactory, no one has lost data and can meet the community's needs for e-money.

\section{DISCUSSION}

In this research regarding the perception of Bandung society on the e-money usage, we concluded that, first, the external variable of the information and technology acceptance is 


\section{Michael Tanu \\ Rita Komaladewi \\ Heni Iswati}

self-efficacy in which the individual is quite sure about his or her ability in resulting action in achieving a certain goal. The society of Bandung city is certain that they are able to properly use and operate e-money in accordance with the procedure. Secondly, the perception of Bandung city society on the usage of e-money is positive because they believe that it helps them accomplish the payment in a faster and precise way. E-money provides security in every transaction and it is more efficient than the cash money. Thirdly, the perception of Bandung city society on the easiness of e-money is positive because they feel that using emoney is very easy, clear to understand, practical and flexible. Fourthly, the Bandung city society perceives that e-money is beneficial as the payment instrument for its easiness, practicality, and flexibility. Thus, they do not have to carry much cash for paying the transactions. Fifthly, the Bandung city society will not always use e-money for microtransaction because there is only a few merchants or businesses in Bandung accepting e-money for the payment, for example, small retailers, copy centers, and street vendors. Sixthly, the Bandung city society is satisfied with the performance of e-money and the time for completing a transaction using e-money is less than ten minutes. Besides, the transaction process is so simple because they just need to tap the card to the scanning device of emoney.

According to our study, it is found that Bandung Society have been welcome to the emoney technology in the form of the card because they just need to top it up before using the card. In order for this service to be better, there should be efforts to introduce this technology to the micro businesses such as small retailers, street vendors, copy centers and others. Regarding this technology, the government needs to make an intervention which can be done by a) conducting continuous and gradual socialization by the Central Bank of Indonesia partnering with the e-money issuing firms, and b) supporting and supervising the usage of e-money to make it more optimum. In addition, c) the service and technology of emoney should be improved to reduce the risk and increase the trust of the society. The last, d) the vendors should provide support to facilitate the e-money payment because there are some of them who do not provide the service of e-money topping up yet.

\section{LIMITATION}

This research has several limitations, one of which is because it is only done in the city of Bandung, so it cannot be generalized. For further research needs to be done in several cities in Indonesia, to see whether it can be generalized or not. Further research can be improved by looking at the service quality of the implementation of e-money to see how people feel. Furthermore the study was conducted using verification methods. 


\section{REFERENCES}

Yang, Y-J. Wang, C-C. ChenC-C. 2016. Recent Development Trend of Electronic Commerce Research: 2000-2016. Contemporary Management Research, Pages 131-142, Vol 13 No 2, June 2017. Doi 10..7903/cmr.1782.

Wulandari, Dwi. (2016). Analysis of the Use of Electronic Money in Effort to Support The Less Cash Society. International Finance and Banking. ISSN 2374-2089, 2016, Vol 3 No 1. Macrothink Institute.

Davis, FD. Bogozzi, RP. \& Warshaw, PR. 1989. User acceptance of computer technology: A comparison of two theoretical models. Management Science, 35, 982-1003.

Fatmawati, Endang. 2015. Technology Acceptance Model (TAM) Untuk Menganalisis Penerimaan Terhadap Sistem Informasi Perpustakaan. Jurnal Iqra', Vol 09 No 01.

Waspada, Ikaputera. 2012. Percepatan Adopsi Sistem Transaksi Teknologi Informasi untuk Meningkatkan Aksesibilitas Layanan Jasa Perbankan. Jurnal Keuangan dan Perbankan, Vol 16 No 1.

Johar, Gapar dan Akmar, Janatul Ahmad. 2011. The Role Of Technology Acceptance Model In Explaining Effect On E-Commerce Application System. International Journal of Managing Information Technology (IJMIT), Vol 3 No 3.

Purwianti, Lily dan Tio, Karen. 2017. Faktor-faktor yang mempengaruhi Behavioural Intention. Jurnal Manajemen Maranatha, Vol 17 No 1, November (2017).

Usman, Rachmadi. 2017. Karakteristik Uang Elektronik Dalam Sistem Pembayaran. Jurnal Fakultas Hukum Universitas Airlangga, Vol 32 No 1. 


\section{Michael Tanu}

\section{Rita Komaladewi}

Heni Iswati

Kotler, P. Armstrong, G. Brown, L. \& Adam, S. 1998. Marketing (4th edition). Sydney: Prentice-Hall.

Lekhanya, LM. Dlamini, HL. 2017. Customer's Perception Towards Product Quality of Automotive SMEs Operating in Metropolitan Areas, and Consideration of Environmental Impact. Environmental Economics, Vol 8.

Liligeto, R., Singh, G., Naz, R. 2014.Factors influencing Consumer Perception toward TV and Newspaper Advertising. The Journal of Pacific Studies, Vol 34 No 2.

Tanu, Michael. 2017. Pengetahuan masyarakat Kota Bandung Terhadap Penggunaan EMoney Studi Kasus Pengguna E-Money. Laporan Tugas Akhir. Unpad 